\title{
HET ACCOUNTANTSBEROEP IN ZUID- EN OOST-AZIË (I)
}

\section{door Drs. Jac. Krikke}

Reeds geruime tijd hebben de accountants uit de landen van Zuid- en Oost-Azië en uit de landen liggend in het zuiden en aan de overzijde van de Pacific behoefte gevoeld aan contact. Het uitwisselen van inlichtingen (in periodieken, enz.) over de ontwikkelingen in het beroep gaat in toenemende mate voort maar de mogelijkheden van directe communicatie waren voor betrokkenen zeldzaam.

De conferenties van Aziatische- en Pacific-accountants zijn daarom van betekenis. Behalve aan de organisatie en werkwijze van het beroep in de bedoelde, naar structuur sterk uiteenlopende landen, schenken zij ook aandacht aan de behandeling van vakvraagstukken.

De eerste van deze conferenties werd gahouden in 1957 in Manilla, de tweede vond plaats in 1960 in Melbourne, de derde werd gehouden in 1962 in Tokio en Kioto. Het laatstgehouden congres vond plaats van 29 november tot 2 december 1965 in New Delhi.

De organisatoren van deze conferentie waren het „Institute of Chartered Accountants of India” en het "Institute of Cost and Works Accountants of India”.

Deze eerste internationale accountantsconferentie, welke in India werd gehouden, werd ondermeer bijgewoond door 1100 leden van de organiserende verenigingen en door 80 beroepsgenoten van 27 beroepsorganisaties buiten India. De werkzittingen waren gewijd aan vijf onderwerpen: Accounting, Auditing, Taxation, Management Accounting en Professional Development. Voor elke sector werd een aantal pre-adviezen geschreven. ${ }^{1}$ ) Het fraaie, met oorspronkelijkheid uitgevoerde, congresboek - dat in twee delen is verschenen - draagt in sterke mate de „,couleur locale" aangezien het voorzien is van vele beschouwingen en illustraties over land en volk, cultuur, bedrijfsleven en andere aspecten van India.

Het is de bedoeling onderstaand iets mee te delen omtrent het beroep in een aantal Zuid- en Oost-Aziatische landen. Hieraan voorafgaand zou als algemene karakteristiek samenvattend een gedeelte kunnen worden weergegeven uit het preadvies van J. A. Wilson, lid van het Canadian Institute of Chartered Accountants, over "International responsibilities of the profession" (geschreven voor het congres 1962 in Japan):

Een tiental jaren geleden werd het openbare beroep in India praktisch uitsluitend geleid door accountants, die hun opleiding hadden ontvangen in het Verenigd Koninkrijk. Nu bestaat het Indiase Instituut, opgebouwd volgens het Engelse patroon. Het Instituut ontvangt steun van de regering (ook financieel). De situatie is thans (1962) zo dat de leiding van de kantoren vrijwel geheel in handen van Indiase partners is overgegaan. In landen als Maleisië, Thailand, Pakistan en Hongkong is men koortsachtig bezig eigen beroepsorganisaties te ontwikkelen. De problemen die daarbij rijzen, zijn vele en

\footnotetext{
1) Ter oriëntering wordt vermeld dat de vier pre-adviezen voor „Auditing” handelden over - The management audit - a vital challenge to the profession to-day;

- Auditors' responsibility with reference to management frauds;

- Management audit - a responsibility and a challenge;

- Internal audit as an aid to management.

Van de pre-adviezen voor "Professional Development" handelden twee over de invloed van de automatisering op de administratie, de organisatie en de controle, twee over de opleiding voor het beroep en één over de functie van de accountant.
} 
groot, omdat deze landen enerzijds zeer oud zijn en anderzijds in deze decennia een ontwikkelingsproces doormaken dat zeer diep en ingrijpend is. Het uitoefenen van accountancy als beroep moet in deze landen letterlijk van de grond af beginnen.

Als tweede voorafgaande opmerking zou een ,accountantsdichtheid" kunnen worden aangegeven (in de helft der gevallen voor medio 1964, voor de andere gevallen medio 1965).

\begin{tabular}{|c|c|c|c|c|c|}
\hline Nederland & één N.I.v.A. - V.A.G.A.-lid & per & 5.066 & der & olking \\
\hline Verenigd Koninkrijk & één chartered accountant & ", & 1.205 & , & - \\
\hline Verenigde Staten & één CPA & , & 2.432 & , & , \\
\hline West-Duitsland & één Wirtschaftsprüfer & , & 29.145 & , & ״ \\
\hline India & één chartered accountant & " & 65.950 & , & ", \\
\hline Pakistan & één chartered accountant & $n$ & 361.000 & ” & , \\
\hline Japan & één CPA & ” & 50.494 & 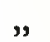 & , \\
\hline
\end{tabular}

Deze getallen geven slechts een zeer ruwe indicatie; voor een reële vergelijkbaarheid zou een aantal correcties moeten worden aangebracht.

Een derde opmerking is, dat in het onderstaande alleen gesproken wordt over de eigen accountants van de verschillende landen en niet over de Angelsaksische e.a. accountants die hier hun praktijk uitoefenen of op andere wijze werkzaam zijn.

\section{INDIA}

Om de ontwikkeling van het beroep aan te duiden, moet men teruggaan tot de "Companies Act" van 1913 die een herziening bracht van de "Indian Companies Act". De wet van 1913 gaf vereisten voor het optreden als ,,auditor" en was als zodanig de primaire reden voor het ontstaan van het beroep. Vóór 1913 mocht men, zonder aan bepaalde eisen te voldoen, controles uitvoeren; nà 1913 mochten alleen personen die een ,certificate of practice” van de regering hadden, naamloze vennootschappen controleren. De wet van 1913 creëerde ook een register waarin zij, die gerechtigd waren tot bedoelde controles, moesten zijn ingeschreven. In 1932 werd ingesteld de „Indian Accountancy Board” en werden de „Auditors' Certificate Rules" vastgelegd.

Nadat het streven naar het autonoom maken van het beroep geleidelijk sterker was geworden, werd dit in 1949 - twee jaar na de onafhankelijkheid - met succes bekroond toen de "Chartered Accountants Act” werd aangenomen die de regeling van het beroep in handen van de beroepsgenoten bracht en daartoe het „Institute of Chartered Accountants of India" in het leven riep. Deze belangrijke gebeurtenis was een sterke stimulans voor de ontwikkeling van het beroep. Een tweede sterke stimulans was de industriële ontwikkeling die een grote behoefte deed ontstaan aan deskundige accountants.

In India bestaat de situatie dat de staat het beroep heeft georganiseerd maar dit gegoten heeft in de vorm van een vereniging. De Indiase regering heeft het Instituut onafhankelijk ${ }^{2}$ ) gemaakt maar met twee uitzonderingen:

a. een vertegenwoordiging in het bestuur (van de 27 leden worden 6 door de Overheid benoemd);

2) Autonomie en onafhankelijkheid moeten o.m. in die zin worden verstaan dat het Instituut geen onderdeel van de Overheid is. 
b. de regelingen die het bestuur treft voor de uitoefening van het beroep, behoeven de goedkeuring van de Overheid.

Het nieuwe instituut $\mathrm{kreeg}$ de zorg voor de regeling van en de supervisie over het beroep en de uitoefening daarvan. Het kreeg tot taak beroepsexamens af te nemen en een opleiding te verzorgen. Wat dit laatste betreft is er een verplichte, schriftelijke opleiding voor de a.s. beroepsgenoten. De examenstructuur heeft sterke overeenkomst met die van Engeland; de vereniging geeft ook de beroeps$\mathrm{kwalificatie} \mathrm{af.}$

Ook in India is de opleiding voortdurend in ontwikkeling. In 1964 was het zo dat men alleen toegelaten werd tot het ,intermediate examination" als men in het bezit was van een universitaire graad ò het nationale diploma in de handelswetenschappen, verstrekt door de „All India Council for Technical Education”, bezat of geslaagd was voor het „preliminary examination” en daarna reeds bezig was met tweede deel van de verplichte praktijkjaren.

Alleen zij die het "final examination" met goed gevolg hebben afgelegd en een praktijkperiode van 4 resp. 8 jaar $^{3}$ ) hebben voltooid, kunnen als lid worden toegelaten.

Pogingen om de cursussen die aan de universiteiten worden gegeven en de opleiding van het Instituut te combineren, hebben tot eind 1965 nog niet tot resultaat geleid.

De beroepskwalificatie is erkend in het Verenigd Koninkrijk en leden van het Indiase Instituut mogen het beroep in het V.K. uitoefenen als zij aan bepaalde formaliteiten van de „Board of Trade” hebben voldaan. In overeenstemming met Engeland - welks invloed op de vorming en regeling van het beroep in India zeer groot is geweest - kent ook het Indiase Instituut „associates" en "fellows"; beide groepen mogen stemmen voor het bestuur maar alleen ,fellows" mogen er deel van uitmaken. Eind 1965 bedroeg het aantal ,associates" 5011 en het aantal „fellows” 2280; tesamen dus 7291.

De „Companies Act" van 1956 versterkte de bepalingen omtrent de controle die de wet van 1913 had gegeven. Iedere vennootschap die onder genoemde wet valt, moet een accountant benoemen, die lid moet zijn van het Instituut.

Het Instituut heeft zich de laatste jaren meer verdiept in de eisen welke de controle stelt; er wordt ook in toenemende mate aan research gedaan. Vermelding verdient het begin van de uitgifte van "Statements on Auditing Practices”, de totstandkoming van „A guide to company audit” (welke in 1962 zijn tweede druk beleefde) en de vaststelling van een "Code of Conduct”.

Met betrekking tot de controle dringt steeds meer het besef door dat de accountant verder moet gaan dan de door de "Companies Act" voorgeschreven controle in engere zin; een beperking tot het oordelen over de jaarrekening bevredigt noch de bedrijven noch de accountant. Er wordt gestreefd naar het meer effectief maken van de "statutory audit"4). Een van de gevolgen hiervan is geweest dat de Overheid - door het aannemen in 1964 van een wijzigingswet m.b.t. de „Companies

3) In India zijn ,articled clerks" en ,"audit clerks"; de laatsten zijn ook in dienst van openbare accountants, maar niet "under articles". De ,articled clerks" moeten 4 praktijkjaren hebben, voor de "audit clerks" geldt het voorschrift van 8 jaar. Het bestuur is doende een verlaging van het aantal verplichte praktijk jaren te bewerkstelligen.

4) Redactioneel artikel in het Indiase verenigingsorgaan "The Chartered Accountant" van juli 1965. 
Act" - de bevoegdheid heeft gekregen om van de externe accountants te verlangen dat zij verder gaan dan tot nu toe en over bepaalde, met name te noemen, aspecten van het bedrijfsgebeuren rapporteren. Even heeft het beroep hierin een aantasting van zijn onafhankelijkheid gezien maar door nadere inlichtingen van de regering o.m. inhoudende dat voorschriften als regel eerst na overleg met het Instituut tot stand zullen worden gebracht - is men weer gerustgesteld.

Het eerder genoemde artikel in ,, The Chartered Accountant” spreekt van nieuwe taken en een nieuwe benadering door de accountant van de „statutory audit". In dit verband mag wellicht ook vermeld worden dat onderwerpen als ,management accounting" een geleidelijk groter plaats innemen, niet alleen bij de vorming van de accountant maar ook in allerlei voordrachten en cursussen voor leden.

Nadat in 1944 door een groep administratieve deskundigen, werkzaam in het bedrijfsleven, een organisatie in het leven was geroepen, is in 1959 door de wet het „Institute of Cost and Works Accountants" ingesteld, dat, evenals het instituut van chartered accountants, een schriftelijke cursus heeft en examens afneemt. Alleen gediplomeerden, die bovendien drie jaar praktische ervaring in „cost accountancy" moeten hebben, worden als lid toegelaten.

\section{PAKISTAN}

In 1950 gaf de Overheid regels voor de deskundigheid van accountants; krachtens de „Auditors' Certificates Rules" werden examens afgenomen door de Overheid waarna men „registered accountant” kon worden. De situatie - ook al bestond er een vereniging van deze accountants - was echter in de ogen van overheid en beroepsgenoten niet bevredigend en men zocht naar wegen tot verbetering.

In 1961 werd, ook door regeling via een wet, opgericht het „Institute of Chartered Accountants of Pakistan". Het Instituut wordt genoemd een ,autonomous body under government control" 5 ). Het bestuur bestaat uit 13 leden waarvan 7 benoemd worden door de Overheid.

Het beroep in Pakistan is nog niet gerijpt. Engelse en Amerikaanse bedrijven in Pakistan worden in overwegende mate gecontroleerd door vestigingen van Engelse kantoren. De basis voor de Pakistaanse accountants om hun beroep te ontwikkelen is nog smal. Een groot deel van het werk dat zij verrichten, wordt gedaan voor of t.b.v. de Overheid. Voor een openbaar accountant is het zakelijk van groot belang dat hij goede relaties heeft met de regering; de Overheid is zijn grootste client.

Enerzijds is deze situatie nadelig voor de ontwikkeling van het vrije beroep maar anderzijds is de hulp en supervisie van de Overheid onontbeerlijk als materiële basis om het te kunnen ontwikkelen. Rahim A. Jan voorspelt dat het nog 15 à 20 jaar zal duren voor het vrije beroep tot volle wasdom zal zijn gekomen. ${ }^{6}$ )

5) Mumtaz Mirza in „Function of public accountants' association”; pre-advies voor het Aziatisch-Pacific Congres 1962 in Japan.

6) Rahim A. Jan in "Operation and organisation of an accountant's office"; pre-advies Congres 1962, Japan. Bij een bezoek aan Nederland in juni 1966 heeft de secretaris van het "Institute of Chartered Accountants of Pakistan" meegedeeld dat vele Pakistaanse accountants de publicatie van Jan betreuren en dat deze bovendien reeds lang door de feitelijke ontwikkeling is achterhaald. De industrialisatie van het land is ook hier een sterke stimulans voor de ontwikkeling van het beroep. 
Het aantal leden bedroeg einde 1965 in totaal 285, waarvan $40 \%$ het openbare beroep uitoefende.

De „,cost accountants” zijn in Pakistan sedert 1951 georganiseerd in het „Pakistan Institute of Industrial Accountants". Deze vereniging ontvangt zowel van de eigen Overheid als van de regering van Canada steun voor haar opleiding en voor de opbouw van het instituut in het algemeen.

Mumtaz Mirza schrijft in zijn eerdergenoemd pre-advies dat de activiteiten van ,chartered accountants” en ,industrial accountants” elkaar completeren, aan welke constatering hij de stelling ontleent dat de beide Pakistaanse verenigingen zoveel mogelijk moeten samenwerken.

\section{CEYLON}

Nadat de „Accountancy Board of Ceylon” een aantal jaren had gefungeerd, is in 1959 het "Institute of Chartered Accountants of Ceylon" ingesteld. Op Ceylon geschiedde dit eveneens door een wet. De structuur van de beroepsorganisatie heeft sterke ovcreenstemming met die van de verenigingen in India en Pakistan.

Aan het eind van 1965 bedroeg het totaal aantal leden 188.

\section{BIRMA}

Het beroep in Birma heeft zich georganiseerd in het „Institute of Incorporated Commercial Accountants".

Deze vereniging, die eveneens het onderscheid kent tussen „fellows” en „associates" (FICA en AICA), stelt niet de eis dat haar leden het niveau hebben van chartered accountant; wel streeft zij naar het geleidelijk opvoeren van de eisen voor haar examens.

\section{THAILAND}

In dit land bestaat het ,Institute of Certified Accountants and Auditors”. Er is geen voorschrift dat men chartered accountant moet zijn.

\section{SINGAPORE}

De staat Singapore heeft in 1963 ingesteld de "Singapore Society of Accountants". Ook hier behoeft men voor het lidmaatschap geen chartered accountant te zijn. Drie van de elf bestuursleden worden door de Overheid benoemd.

\section{MALEISIË}

Sedert 1958 bestaat in dit vanaf 1957 onafhankelijke gebied de „Malaysian Association of Certified Public Accountants", welke vereniging zich tot heden in sterke mate heeft beziggehouden met het afnemen van de beroepsexamens.

Wij komen hiermee in cen gebied met beroepsorganisaties waar - anders dan in de zojuist besproken landen - de Amerikaanse invloed duidelijk merkbaar is in de wijze waarop het beroep is georganiseerd. Het is de bedoeling hierop in een tweede en derde beschouwing in te gaan. 